\title{
The Role of Cultural Competence to Overcome Intercultural Communication Conflict: Case study of Indonesian and Korean students in Kyungsung University, South Korea
}

\author{
Dr. Bertha Sri Eko Murtiningsih \\ Multimedia Nusantara University, Tangerang, Indonesia \\ Email: bertasri@umn.ac.id
}

\author{
Doi:10.5901/mjss.2016.v7n6p213
}

\begin{abstract}
Intercultural communication is a growing interest in the realm of global communication science and students pursuing degrees across the borders of nation-states. Nevertheless, the practice of intercultural communication does not always go effectively. This paper addresses problematics of intercultural communication occurred between Indonesian and South Korean students in Kyungsung University, Busan, largely nuanced by prejudice, stereotypes, ethnocentrism as well as values differences about social drinking culture, friendship, beauty, seniority, and perception on punctuality, which consequently trigger misunderstanding that leads to conflict. The goals of this study are twofold, namely, first, to gain deeper understanding on sources of intercultural communication conflict between Indonesian and South Korean students, secondly, to highlight the role of cultural competence to overcome conflict. The method of the research is case study with in-depth interview as the information gathering technique. The result will show that problems in intercultural communication are to a greater extent influenced by two inter-related attitudes which is cultural insensitivity and lack of cultural competence such as respect, socio linguistic awareness, deep cultural knowledge, and skills to listen and observe. The paper will also point to problem-solving alternative to reduce intercultural communication conflict both for Indonesian and South Korean students, namely to develop a more subtle approach when encountering religious-held beliefs with socially accepted norms.
\end{abstract}

Keywords: cultural competence, intercultural communication, intercultural conflict, cultural insensitivity

\section{Research Background}

The growth of intercultural communication in the realm of education is indisputable due to the increasing numbers of opportunities for students to continue their studies abroad. Consequently, intercultural communication is a necessary condition for students to interact and to make meaningful contact with different cultures. Communities imbued with differences in culture(s) will create distinctive communication patterns. Those distinctive patterns, either verbal or nonverbal, may be accountable for different sets of meanings, which eventually end up in strained relationship.

Intercultural communication problems, such as individual and social conflicts, identity crisis, culture shock and inferiority complex attitude, may imply to several aspects in the lives of Indonesian students who pursue their degrees in South Korea. For years, Indonesian students pursuing their studies abroad are limited to mastering cognitive knowledge, but lacking in familiarity with practical knowledge such as intercultural communication competence. This lacking of competence is highly crucial due to the fact that many Indonesian students having interest to study abroad, especially to South Korea (Latief, 2015), but they lack a vital competence, namely cultural competence.

This lack of competence will eventually trigger intercultural communication conflict, which is very complex by nature due to interrelated cultural factors such as, but not limited to, system of beliefs, values, thinking patterns, communication patterns, and the way each culture perceives and deals with conflict. Intercultural communication conflict seen as a threat can take place in several settings and contexts, either in interpersonal, organizational as well as larger intersocietal relationships. Conflict is commonly perceived as proper in every types of relationship as long as it is managed well. But, several cases show that conflict can also become bad influence for parties involved.

Yu (1995, in Liu, S. and Chen, G. M., 2000) once observed that as intercultural communication grows, there also arises opportunities to understanding as well as conflict. Therefore, understanding and managing conflict in intercultural communication is increasingly significant. It takes intercultural communication competence to overcome conflict.

In this context, the author will argue on the importance of Intercultural Competencies as an approach to overcome intercultural conflict, especially with regards to Indonesian students pursuing higher degrees of education in South Korea. It is believed and be justified that Intercultural Communication Competencies can become an effective means "to facilitate the learning of students from multiple cultural backgrounds while providing them with the skills to succeed in an 
increasingly culturally diverse world." (Cushner, K. and Mahon, J. in Deardorff, D. K., 2009:307).

Some more words on the definition of the central term used in this paper. Deardorff, D. K. (2009:6) is of the opinion that "Competence has been variously equated with understanding (e.g., accuracy, clarity, co-orientation, overlap of meanings), relationship development (e.g., attraction, intimacy), satisfaction (e.g., communication satisfaction, relational satisfaction, relational quality), effectiveness (e.g., goal achievement, efficiency, institutional success, negotiation success), appropriateness (e.g., legitimacy, acceptance, assimilation), and adaptation." It is also emphasized that "intercultural competence is the appropriate and effective management of interaction between people who, to some degree or another, represent different or divergent affective, cognitive, and behavioral orientations to the world. These orientations will most commonly be reflected in such normative categories as nationality, race, ethnicity, tribe, religion, or region" (Deardorff, D. K., 2009:7)

The significance of this research lies on the observable fact that intercultural conflict and culture shock experienced by Indonesian students in South Korea are on the rise. This kind of conflict tends to instill negative sentiment both on individual levels as well as societal one. Some Indonesian students are discouraged to continue their studies further or working in South Korea because of their inability to cope with Korean culture.

\section{Theoretical Perspective}

\subsection{Intercultural Communication and Conflict}

Intercultural communication is the buzzword in today's global communication studies. Effective intercultural communication is believed to help someone to develop a more meaningful relationship. Therefore, intercultural communication tenets are those important to learn and be understood for people coming from various backgrounds. In general, intercultural communication is about communication between people who have different cultural traits such as beliefs, values and way(s) of conduct.

Samovar, L. A., Porter, R. E., and McDaniel, E. R. (2010:13) offers the view that intercultural communication happens when a member from a certain culture sends message to another member from other culture. Intercultural communication involves interactions between persons who have differences in their perception and symbolic system, within communication setting.

Typically, it is believed that intercultural communication is a complex process because when some individuals involved in a cultural communication, each participant operates within sets of distinctive rules. Understanding differences in rules would facilitate participants to avoid misunderstanding which potentially leads to cultural conflict.

Intercultural communication conflict may be caused by certain stereotypes, prejudices, ethnocentrism and inappropriate verbal or non verbal behavior when establishing communication with people from different cultures. Pepper, G. L. in Samovar, L. A., Porter, R. E., and McDaniel, E. R. (2010:383), affirms that both communication and culture play significant role when conflict breaks. If taken carelessly, communication is a dominant force of conflict because communication can function as a tool to spread conflict as well as the source to manage conflict. Culture determines how conflict is perceived and managed.

Martin, J. N. and Nakayama, T. K. (2010:426) proposes that intercultural conflict is unavoidable and it happens in multilevel stages, namely in interpersonal, social, national and international ones. The light of understanding on the nature of intercultural conflict is vitally needed because there is a close relationship between culture and conflict. It means that cultural differences can lead to conflict. How individuals determine conflict, proper and improper issue to be discussed in conflict, as well as how to resolve conflict is highly influenced by culture.

DeVito, J. A. (2009:281) confirms that conflict is influenced by participant's culture, especially system of beliefs and their values about conflict. Culture informs topics regarding proper and improper ways to deal with conflict. Topics in conflict are also dependent on the kinds of culture that puts them into context, whether it is low or high context. In high context culture, conflict is centered around the violation of group values and norms, while in low context culture, it is more on the individual values and norms. Culture is also shaping participants' willingness and skill to create conflict strategy. For instance, society with collectivist culture tends to avoid conflict in order to saving faces of the members.

\subsection{Intercultural Communication Competence}

Having intercultural competence will significantly help individuals to establish an effective intercultural communication. The nature of intercultural communication competence is very complex because it involves both individual perspective as well as others' perspective in order to evaluate the appropriateness of behavior and communication. 
According to Spitzberg, B. H. in Samovar, L. A., Porter, R. E., and McDaniel, E. R. (2010:425), "Communication competence is defined as social behavior that is perceived as relatively appropriate and effective for a given context."

Deardorff, D. K. 'Process Model of Intercultural Competence' which is aptly termed "Causal Path Models" (2009:33) is a very useful tool to depict highly interdependent systemic processes in which both interlocutors are simultaneously providing inputs and outputs into the system (Deardorff, D. K., 2009:29). See figure 1.1. below.

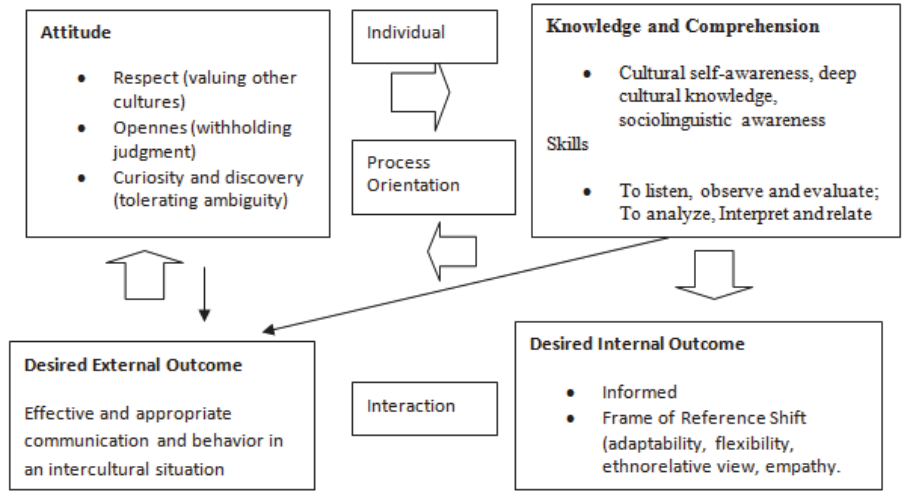

Figure 1.1. Process Model of Intercultural Competence (Deardorff, D. K., 2009:33)

\subsection{South Korean Culture}

\subsubsection{Social Drinking}

Korea is one of the most developed countries in Asia with a unique culture that retains the original culture but somewhat influenced by Western culture. A Korean cultural aspect not eroded by modernization is social drinking, both among the young and the old, whether in interpersonal or in organizational relationships, to make friends with others.

Sargent, M. (1979:83, in Rismawati, 2011:12) observes that social drinking is a habit of the Korean people to socialize over a drink with colleagues, superiors, or family members. Socialization by means of drinking to get drunk is considered creating a warm atmosphere, a sense of brotherhood, and increasing trust among them.

Soju is a popular beverage that is inherited from generation to generation and has become a symbol of social life. Recognizing Soju is one way to get to know Korean society more closely in the personal, education, and business environment. The symbolic meaning of Soju as part of social action for the Korean society seems not yet fully understood by foreigners as Indonesian students who are studying in the country. Most of Indonesian students are somewhat surprised by the way Korean students build friendships by getting a drink. Differences in values, religions, and norms give a different perspective. Therefore, there are some Indonesian students, especially Muslim ones, who interpret social drinking by using negative lens.

Social drinking is a means to be familiar with the atmosphere and to reduce stiffness during formal meetings. Therefore, it is a must for people to be invited for a drink. Rejecting the offer will make the atmosphere rigid and we could be considered less appreciated, especially by the superiors. This culture is so embedded in Korean society because the society supports social drinking habits. They are generally less tolerant of people who can not drink for health, norms, and religious reasons.

\subsubsection{Seniority}

One important cultural value in Korean society is seniority. Koreans respect older people. Mahayana, M. S. (2011:120) is of the opinion that Korean people give a good place to older people. This value is represented in the facilities given by the government to parents, such as the existence of schools, playgrounds, sports facilities specifically designed for them. In addition, people supposed to be retired are still employed for jobs that do not require much intellectual prowess and great energy.

Parents have a place of honor in the family, and younger people are obliged to respect those who are older. On the 
other hand, seniority often makes senior positions tend to be more powerful against juniors. To show the dominance and influence, usually older people talk with high intonation to younger age and position. In the context of this study, seniority is also indicated among students in Korea. They also impose this value to foreign students. Those in lower levels should give priority, respect and follow the wishes of more senior students.

\subsubsection{Beauty and Plastic Surgery Concepts}

Physical Appearance is an important factor for Korean young generation, therefore they are very concerned about their appearance, including make up, clothes, and accessories they use. Appearance represents one's personality. When a person looks nice and pretty, she is considered capable of taking care of her own. If someone can take care of herself it means that she is able to take care of her job. With beautiful and attractive appearance, then the chances of getting a job will be greater.

The high value of beauty among young Koreans enables them to fix their appearance through a special way, namely plastic surgery. Wahyudi (2011:29) observes that most Korean parents support, even advise their children to perform plastic surgery to enhance the confidence of the children. The concept of beauty for Korean people is a bit different from the concept of beauty typically found in other Western countries in general. For Korean people, beauty is identical with pointy chin, having eyelid crease, sharp nose, small mouth, and wide eyes, and less fat under the eyes. Celebrities have become 'beauty's terms of reference' for Korean teens.

\section{Aims of Study and Research Method}

This research is aimed at finding and reformulating (1) problematics of intercultural communication between Indonesian and South Korea students, (2) intercultural competencies and conflict.

This study uses qualitative approach with case study method. The case study method is developed by Stake, R. E. (2003) and in this study, I owe the method and the definition on Stake's elaborative notion of instrumental case study in which 'the case plays a supportive role and facilitates understanding of something else', namely Cultural Competence.

The selection of informants is determined with purposive sampling technique wherein the study itself categorizes kinds of informants properly chosen for sampling. By certain criteria based on the aims of the study, the selection of informants is taken into action. For this study, the criteria of participants are:

1. They have stayed in South Korea for minimal one year

2. The age of the participants are above 20 years

3. They have a basic understanding of Korean Language

The Author of this study uses information gathering technique through in-depth interview. The interview itself was carried out by the author in Focus Group Discussion (FGD) setting, comprising of seven students, located in Busan, South Korea. The author conducted FGD in three sessions, in which each session approximately took two hours. The interview sessions were carried out in the second week of October 2013.

Table 1: Demographic of participants

\begin{tabular}{|c|l|c|c|c|c|c|}
\hline No. & Name of participants & Age & Ethnicity & Education & Length of Stay in Korea & Religion \\
\hline 1 & E. Byan Wahyu Riyandwita & 23 & Javanese & Doctoral & 7 years 7 months & Catholic \\
\hline 2 & Amanda & 23 & Javanese & Bachelor & 4 years & Islam \\
\hline 3 & Virgin & 22 & Javanese & Bachelor & 3 years & Catholic \\
\hline 4 & Mieske & 22 & Chinese & Bachelor & 3 years & Catholic \\
\hline 5 & Gregorius Rio Nugroho (Rando) & 23 & Javanese & Master & 1 year & Catholic \\
\hline 6 & Alenxa Xinia & 23 & Padang & Bachelor & 4 years & Islam \\
\hline 7 & Gabby & 23 & Chinese & Bachelor & 3 years & Catholic \\
\hline
\end{tabular}

\subsection{List of questions addressed to participants of Focus Group Discussion as instrument interview}

1. Describe your view about character of Korean people!

2. Describe your experience while interacting with aspects of Korean culture (such as: social drinking, seniority, etc.)

3. What are notable character differences between Indonesian and Korean people? 
4. How do you perceive obstacles in interaction regarding character differences between Korean and Indonesian people?

5. What are positive and negative characteristics of Korean people while interacting with Indonesian people here?

6. What are your obstacles in communicating with Korean people?

7. How do you describe your communication situation between you and Korean students? Are they formal/informal, intimate/not, with humor/humorless?

8. How do you perceive Korean students' attitude while interacting with Indonesian students? Are they open or closed by nature?

9. Do they frequently blame other people or not?

10. What is the main cause of intercultural communication conflict between Indonesian and Korean students?

11. If the conflict happen, does each party address the conflict immediately and find the solution or not?

12. What are supporting factors of intercultural communication between you and Korean students (such as: empathy, tolerance)?

13. What is the necessary competence that should belong for both parties in order to resolve the arising conflict?

\section{Research Finding}

\subsection{Intercultural communications' problematics between Indonesia and South Korea college students in Kyungsung University}

For majority of Indonesian students studying in South Korea, especially in Kyungsung University located in the city of Busan, the issue of cultural differences brings significant influence to their interaction and communication with local students. The cultural differences include level of formality within interaction; the value of friendship; face expressions; taboo matters; and chronemics. Such cultural differences can lead to prejudice that eventually will bring up stereotypes and discrimination.

An informant, Virgin (22), revealed that there is a domination based on the seniority during her interaction with local students. Lower level students, she said, should respect senior students. This condition does not reflect her values. In her Indonesian culture, comity to others-especially in the context of interaction with schoolmates-should not be based on seniority.

Virgin also found that the Korean custom of social drinking as a way of acquaintance with new friends, to be annoying. She admits that sometimes she could not refuse the invitation as it was considered impolite.

"I even have to find excuse (usually about my health condition) in order to refuse their invitation for social drink. In my country, we never find such a thing. If we want to get acquainted with someone we met recently, we just chat..." (Virgin, email, September 22, 2013)

I was asked to eat pork-based meals, as well as drinking and smoking and I can not refuse the invitation, even though all those activities are prohibited within my religion. Later on, I was reluctant to eat together with them because I was not allowed to eat pork-based meals. For drinking, I was forced to learn drinking habit within organization in order to maintain good relationship with them. They consider drinking buddies who got drunk as the best of friend. (Amanda)

There are two important settings where liqueur comes into the circle of socialization, namely to reduce stress and to overcome problems. To most members of Korean society, drinking is considered as a means to release pressures they experience and also to make relationships more intimate. If there are tensions between them, liqueur is also used to break the ice and to empower them to express their heart's content regarding problems they are facing. (Rando)

Moreover, Virgin stated that race discrimination and stereotype have been commonly practiced by local students when they interact with foreign students. She exemplified that the Korean students tend to be friendlier to Caucasian race than to Asian. In fact, black people are considered "low." Virgin also said that she was being stereotyped as a "thirdworld people" just because she is Indonesian.

"They also limit physical contact, especially when communicating with foreigners. Koreans on the one hand want to seek harmony in relationships, but on the other hand they are often emotional when things are not like what they expect on us. They don't see us as what we are." (Virgin, email, September 22, 2013) 
Another communication barrier that is often experienced by Indonesian students is the lack of understanding of taboo issues. As Virgin said, Koreans are very sensitive to talk about politics and physical nature like weight, height, and age. In contrast, in her culture, what's considered taboo is talking about sex while asking physical nature statistics (weight, height, and age) is, in fact, a way to build a strong relationship.

Although Korean basically adopt collectivist culture (DeVito, J. A., 2009), but in reality, they tend to be individualistic (Ahn, D. D., 2011). As stated by Virgin, Korean students are self-centered as they only focus on their interests without caring for others. In terms of nonverbal communication, Indonesian students often find Korean students to be unable to express their feelings. Nonverbal communication through facial expressions is rarely done and found. Moreover, when they talk, most of them used paralinguistic (high intonation) that often been misinterpreted as anger by foreign students.

Chronemics, the study of time, which is a significant area of nonverbal communication as viewed by Hickson, M. L. and D. W. Stacks (1989, in Lee, 2009:120), is an essential matter in South Korea that has been overlooked by Indonesian students. As a result, Indonesian students tend to find it more difficult to adjust themselves with the punctuality of the Koreans. They cannot tolerate seeing people do not come on time (Virgin, email, September 22, 2013).

Intercultural communication problem arises when South Korean students demand Indonesian students to show their beauty according to South Korean beauty concept.

For Korean society, plastic surgery is a common practice. When celebrating birthday, the mother typically asked the daughter whether they want birthday gift or operation (surgery). The parents are usually suggesting operation, such as eyes, orthognathic surgery, lip augmentation, and the next year is nose job. What makes us feel uncomfortable is that they (Korean) use their own standards and concepts to measure our (Indonesian) beauty. They seem like to impose their culture towards others. When I go out with my fellow Korean gang, they used to mock me, such as: my dry hair, or for not using eyeliner, or face powder. Make up is a really serious thing for them. (Alenxa)

Beauty is really important for Korean teenagers. That is a valid thing to consider. But what I object most is when they choose friends by using the standards of (their own) beauty. They will befriend those who they consider attractive, cool, and using top brand (Virgin)

As stated above, one of the most important values in Korean society is seniority. They respect elders very deeply. South Korean students apply this 'seniority principle' in socialization as well, but not always in appropriate manner. It is commonly found that elders or more experienced people tend to enjoy priority and even impose their wills to juniors. In this study, senior Korean students treat their Indonesian junior with less respect.

\begin{abstract}
When seniors talk to their juniors, they use high intonation, even yelling. Elders also tend to use high intonation while talking to young people. On the contrary, young people have to follow elder's wills. In my opinion, the seniority applies here is more on the negative level, because the principle is used in their (elder) favor or to bargain position to a higher degree to impose their volitions (Meiske)
\end{abstract}

Seniority culture is shown extravagantly in the campus. When passing by seniors, juniors are complied to greet. Otherwise, it is considered improper. In meetings amongst associates, such as social or church gatherings, juniors have to address their seniors, especially those who hold position as the head in that association, complete names with the position accordingly. They create unbridgeable gap, even though they are just friends in campus. (Gabby)

According to one of the informants' testimony, E. Byan Wahyu Riyandwita, the most prominent values of the Korean people are seniority and social status. Seniority is an absolute measure to gain respect and placement in social status, but the placement of social status, especially social position, still influences interaction in Korean society.

The value of friendship found in South Korean students is mostly based on materialistic and utilitarianistic principles. It is different compared with Indonesian students who base their friendship on loyalty and togetherness values. This discrepancy of values quite often creates tension and conflict amongst them. One of the informants share her thoughts as follows:

In nurturing sense of friendship, they tend to use the utility and benefit principle. To put it bluntly, they will aske themselves, can we benefit by befriending him/her? They also tend to see other people (strangers) through negative lens. They dislike giving motivation or encouragement, nor sense of togetherness. Meanwhile, the base or motive to bond friendship in Indonesia does not solely depend upon the principle of benefit, nut rather on the loyalty, solidarity and sense of togetherness. Korean society tends to see friendship like investment and they will seek benefits as many as they can gather. They show friendship so long as it is beneficial for them. The 'friends with benefit' principle works pretty well here. (Alenxa) 
Other Indonesian students share the same view that Korean friendship is more often just a lip service. Koreans would rather have many friends than just a few friends. They prefer having many acquaintances to having a few close friends. They are more concerned with quantity than quality. Below are comments on the underlying issue of friendship:

There is a lot of competition going on here. A friend of mine in English class, a Korean, considers myself as a bright student. Then, he approaches me to help him learn English. In other class, he befriends with my so-so friend. My so-so friend is gradually left behind because he searches for a cleverer student to befriend with, in order to gain the level of knowledge until reaching equal position. At times, they also choose friends who have a higher financial level (richer). Having possessions is really influential to bond a friendship for Korean students. (Virgin)

While Indonesians are more concerned with friendship, Korean friends do not cultivate genuine friendship, just pleasantries. In stark contrast, the style of friendship in Indonesia emphasizes loyalty and togetherness. (Amanda)

\subsection{Developing Cultural Competence to Overcome Intercultural Communication Conflict between Indonesian and Korean Students}

After conveying several principles of cultural competence and students' experiences of intercultural communication, the core questions in this paper should now appear like this: First, why students from Indonesia and South Korea are unable to overcome the conflict effectively after enduring years? and Second, what tools or attitudes should be embraced in order to progress towards conflict resolution that satisfy both parties involved?

As a guiding principle, Spinthourakis, J. A. (2006:645) underlines that as "contact with another culture will modify cultural identity, both consciously and unconsciously," nevertheless, "cultural contact should be seen as a source of enrichment, not of conflict."

Communication that has occurred between Indonesian and Korean students as portrayed above has largely been painted with negative comments. Most of Indonesian students studying in Kyungsung University felt uncomfortable when establishing intercultural communication with fellow Korean students. If this trend continues without proper evaluation and willingness to change, it is believed that the hatred felt by Indonesian students towards any Korean cultural markers and attitudes will drive them further towards withdrawal or limiting of interaction with fellow South Korean students.

Unmanageable conflict is also perceived due to the factor of both Indonesian and South Korean students' cultural insensitivity as well as lacking in cultural competence. Based on Deardorff, D. K.'s Model of Cultural Competence (2009), Indonesian and Korean students do not have these cultural competencies, namely respect, knowledge and comprehension such as deep cultural knowledge and sociolinguistic awareness

Below, the author will present a comparative table consists of three columns, namely, lack of competence, description on the Indonesian students, and description on the South Korean students, in terms of each marker of Cultural Competence

Table 2: Comparison of Lack of Cultural Competence found in Indonesian and South Korean Students

\begin{tabular}{|l|l|l|}
\hline Lack of Competence & Indonesian students & South Korean students \\
\hline Attitude (Respect) & $\begin{array}{l}\text { Indonesian students tend to show rigid attitude } \\
\text { and not flexible to accept South Korean } \\
\text { students' perception on friendship. They tend to } \\
\text { avoid getting involved in socialization } \\
\text { (pergaulan) }\end{array}$ & $\begin{array}{l}\text { 1. South Korean students tend to lack commitment in } \\
\text { fostering relationship with Indonesian fellow students } \\
\text { 2. South Korean students tend to treat friendship based } \\
\text { on the principles of utility and profit-searching } \\
\text { 3. Racist attitude is shown towards fellow Indonesian } \\
\text { students }\end{array}$ \\
\hline $\begin{array}{l}\text { Knowledge and } \\
\text { Comprehension } \\
\text { (sociolinguistic awareness) }\end{array}$ & $\begin{array}{l}\text { Indonesian students tend to miss the meaning of } \\
\text { specific idioms of Korean language according to } \\
\text { cultural context of Korean society and norms } \\
\text { language seriously. They tend to communicate only with } \\
\text { those who can speak Koreanese language. } \\
\text { 2. They tend to isolate fellow Indonesian students who do } \\
\text { not speak Koreanese. }\end{array}$ \\
\hline $\begin{array}{l}\text { Knowledge and } \\
\text { Comprehension (self- } \\
\text { knowledge) }\end{array}$ & $\begin{array}{l}\text { Indonesian students tend to hold negative } \\
\text { krejudice towards Korean social drinking, } \\
\text { friendship and beauty. }\end{array}$ & $\begin{array}{l}\text { 1. South Korean students do not show tolerant and } \\
\text { empathy attitude. They tend to hold negative prejudice } \\
\text { towards Indonesian students refusing social drinking } \\
\text { culture. } \\
\text { 2. Isolating Indonesian students who refuse to participate } \\
\text { in social drinking culture }\end{array}$ \\
\hline
\end{tabular}




\begin{tabular}{|c|c|c|}
\hline Lack of Competence & Indonesian students & South Korean students \\
\hline $\begin{array}{l}\text { Skills (to listen, observe, \& } \\
\text { evaluate) }\end{array}$ & $\begin{array}{l}\text { 1. Indonesian students tend to observe situation } \\
\text { and condition before expressing thoughts on the } \\
\text { matter, and they tend to withdraw from the } \\
\text { problems when they see bad consequences will } \\
\text { impact for them. It takes a little more time to } \\
\text { resolve problems and overcome conflict } \\
\text { 2. In dealing with conflict, they tend to be not } \\
\text { flexible and also adopt point of view from own } \\
\text { culture }\end{array}$ & $\begin{array}{l}\text { 1. South Korean students lack the skill to listen to other's } \\
\text { opinion, ideas and complaints expressed by Indonesian } \\
\text { students } \\
\text { 2. Mastering conflict and apply win-lose strategy in } \\
\text { dealing with conflict } \\
\text { 3. Not flexible to deal with conflict and tend to use their } \\
\text { own point of view } \\
\text { 4. Insensitive towards norms and rules from other cultures } \\
\text { as well as insensitive towards other culture's perceived } \\
\text { taboo issues. }\end{array}$ \\
\hline
\end{tabular}

Based on table 2 above, we may safely assume that South Korean and Indonesian students' inability to respect other culture and lack of deep knowledge about cultural differences, as well as incapacity to listen to each other voices give way towards impropriety in behavior and communication within the setting of intercultural communication. This impropriety appears in egocentrism, isolation and withdrawal attitude, ethnocentrism, and inflexibility towards differences. These improprieties worsen the conditions of conflict between them.

\section{Discussion and Conclusion}

Values differences, ways of communication, modes of thinking, stereotypes and ethnocentric point of view in intercultural communication are highly related factors in triggering conflict. Conflict between Indonesian and South Korean students are not effectively managed and solved due to cultural competence they are lacking. Both Indonesian as well as South Korean students are necessarily encouraged to understand and to develop cultural competence proper in order to help them solving the conflict they face.

One specific factor of intercultural communication obstacle stands out from the conversation (testimonies) cited here, namely the role of religious norms vis-à-vis social norms which is perceived differently by Indonesian and Korean students alike. When asked to get involved in 'social drinking' (which is a normal social norm for Korean people) and to eat pork-based meals (which is a common culinary taste among Koreans), some Moslem students initially object to the invitation because their religious norms prohibit them from taking parts in such activity and taste such culinary. But later, they have to comply, in order to be socially accepted. There is an underlying conflict here between Indonesian Moslem religious norms and Korean acceptable social norms, which is, to a large extent, neglected in Deardorff, D. K. model of Cultural Competence pictured above.

Some of the students interviewed here also acknowledge that they feel they are "losing their basic identity" of being an Indonesian, namely, a religious-affiliated norms and values bearer, the more they comply with socially accepted norms and behaviors of fellow Korean students, specifically in social drinking and pork-eating activities. Some even experience 'values disorientation' after several attempts to comply with the invitation. To put it succinctly, they experience a "losing initial identity by blending into another new identity" case. Critically formulated, is it the case that will become an exemplary for all Indonesian students pursuing degrees in South Korea in the future?

Cultural sensitivity is a notable factor in fostering a healthy intercultural communication which, if neglected, will create a cultural tension and can become a cultural conflict if prolonged without proper attention. Cultural competence as argued in this paper will not be complete without taking into consideration the cultural sensitivity to build a healthy and lasting intercultural communication through self-awareness and respecting others' frame of cultural (or religious) reference. In Dusi, P., Messetti, G., and Steinbach, M. voice (2013:545), "in the heart of the ICC you can find selfawareness, which is also awareness of the cultural frame that guides its own eye view on the world, and it allows an elaboration of one's own experience and habitus and a continuous sharpening of a receptive sensitivity with respect to another."

South Korean students is better equipped if they develop the knowledge and comprehension skills related with sociolinguistic awareness. Indonesian students in South Korea should also develop Knowledge and Comprehension competence, including self-awareness and deep cultural knowledge, in order to become more flexible in seeing and understanding cultural difference, especially on social drinking, which in South Korean society's eyes, is having a very significant meaning and also part of long-standing tradition. Cultural knowledge is important to reduce the backlash of having prejudice and streotypes. Indonesian students in South Korea should also have cultural sensitivity, realizing subtle differences, such as ways of communication, how to understand pitch and intonation in proper context, and how to use communicative touch appropriately. South Korean students generally do not want to touch and be touched by strangers. 
South Korean students should also develop attitude competence, by respecting other nations, not discriminating against foreign students, and not forcing their own cultural differences towards people coming from various regions and nations.

To overcome intercultural conflict, both Indonesian and South Korean students should also develop cultural skills such as listening, observing, and evaluating factors triggering conflict. Courage to express conflict with honesty and willingness to negotiate conflict, and not avoiding conflict, are qualities to overcome conflict effectively.

\section{References}

Ahn, D. D. (2011). "Individualism and Collectivism in a Korean Population". Scripps Senior Theses. Paper 107. [Online] Available: http://scholarship.claremont.edu/scripps_theses/107

Cushner, K. and Mahon, J. (2009). Intercultural Competence in Teacher Education Developing the Intercultural Competence of Educators and Their Students: Creating the Blueprints. In Deardorff, D. K. (Ed.) The SAGE Handbook of Intercultural Competence. London and California: SAGE Publications, Inc.

Deardorff, D. K. (Ed.) (2009). The SAGE Handbook of Intercultural Competence. London and California: SAGE Publications, Inc.

DeVito, J. A. (2009). The Interpersonal Communication Book, $12^{\text {th }}$ International Edition. New Jersey (USA): Pearson Education, Inc.

Dusi, P., Messetti, G., and Steinbach, M. (2013). Skills, Attitudes, Relational Abilities \& Reflexivity: Competences for a Multicultural Society. In Procedia - Social and Behavioral Sciences 112 (2014) 538 - 547.

Latief. (2015). "Tertarik Mengenal Korea dan Cari Beasiswa ke Negeri Ginseng Itu?" In Edukasi Kompas.com [Online] Available http://edukasi.kompas.com/read/2015/05/30/11560081/Tertarik.Mengenal.Korea.dan.Cari.Beasiswa.ke.Negeri.Ginseng.Itu.

Lee, Y. O. (2009). Perceptions of Time in Korean and English. Human Communication. A Publication of the Pacific and Asian Communication Association. Vol. 12(1), 119 - 138.

Liu, S. and Chen, G. M. (2000). Assessing Chinese Conflict Management Styles in Joint Ventures. In Intercultural Communication Studies IX-2, 71-88. [Online] Available: http://web.uri.edu/iaics/files/4-Shuang-Liu-Guo-Ming-Chen.pdf

Martin, J. N. and Nakayama, T. K. (2010). Intercultural Communication in Contexts. $5^{\text {th }}$ Edition. New York: McGraw-Hill.

Mahayana, M. S. (2011). Pusparagam Budaya Korea: Cerita Rakyat Korea-Indonesia: Pembentuk Karakter. Yogyakarta: Inakos Publisher (The International Association of Korean Studies in Indonesia) in collaboration with Korean Study Center Gadjah Mada University

Rismawati. (2011). Budaya Minum Sul Dalam Kehidupan Masyarakat Korea. An Undergraduate Thesis. Korean Language and Cultural Studies Program, Faculty of Humanities, Universitas Indonesia.

Samovar, L. A., Porter, R. E., and McDaniel, E. R. (2010). Komunikasi Lintas Budaya: Communication between Culture, Edisi 7. Indonesian translation. Jakarta: Salemba Humanika

Spinthourakis, J. A. (2006). Developing Multicultural Competence through Intercultural Sensitivity. In International Journal of Migration Studies. Studi Emigrazione/Migration Studies, XLIII (163), 641-656.

Spitzberg, B. H. (2012). Axioms for a Theory of Intercultural Communication Competence. In Samovar, L. A., Porter, R. E., and McDaniel, E. R. Editors. Intercultural Communication: A Reader. 13th Edition. Boston (USA): Wadsworth Cengage Learning.

Stake, R. (2003). Case studies. In N. K. Denzin \& Y. S. Lincoln (Eds.), Strategies of qualitative inquiry (2nd Ed.) (pp. 134 - 164). Thousand Oaks, CA: Sage.

Wahyudi, I. (2011). Pusparagam Sosial-Budaya Korea: Operasi Plastik Generasi Muda Korea, Yogyakarta: Inakos Publisher (The International Association of Korean Studies in Indonesia) in collaboration with Korean Study Center Gadjah Mada University 
ISSN 2039-2117 (online)

ISSN 2039-9340 (print)
Mediterranean Journal of Social Sciences MCSER Publishing, Rome-Italy
Vol 7 No 6 November 2016 